\title{
The Importance of How Regions are Constructed
}

\author{
Roger Nyqvist
}

\begin{abstract}
In this article the author discuss how many regions can be identified in the province of Bohuslän. Region is a construction that covers everything from landscape, people and economic structure, to nature, political structure and structures for subsistence. We have to keep this fact in mind, because these aspects, will be the reasons for how and why our material remains have the shape and distribution that they do. Different materials within the region can also be the result of the agricultural history, as well as the influences of the interested group of collectors could create for the artefacts. Therefore it seems most correct to use the term region only in the geographic sense.
\end{abstract}

Roger Nyqvist. Bohusläns Museum, Box 403, SE-45I 19 Uddevalla, Sweden.

Key words: Bohuslän, region, skeppsredor, sign, symbol, medieval, Iron Age.

\section{INTRODUCTION}

This is an article that is to a part extracted from my doctoral thesis. The main issue is to try to argue around questions such as how many regions can be identified in the province of Bohuslän, which forms part of the region called western Sweden. In one sense this region seems to be anything but a united area. More specifically Bohuslän is the coastal area within the newly created county of Västra Götaland. The county of Västra Götaland contains most of the geographic area that is usually recognised as the region of western Sweden; only a few provinces are missing. Because the region of both western Sweden and Västra Götaland contains different types of nature, topography and consequently different resources, I shall start this article by discussing what are regions and how do we detect them. Thereafter I will try to illuminate this by putting together the available information from historical, archaeological and ethnological works. In this article I will also discuss how difficult it is to build an argument on material without knowing its history or at least discussing it.

I will also discuss the importance of when and how our archaeological material is created and compare this with the possible interpretation of the artefacts and the monuments. The archaeological material that I will use is mainly from my own research on two districts in the province of Bohuslän, as well as from the work of Ingegärd Särlvik from 1982. 


\section{A DISCUSSION ABOUT WHAT CONSTITUTES A REGION}

What is a region? Can a region be defined so that we can distinguish borders between the different regions? Regions can, as I see them, in one sense even have the same meaning as words like "society" or "sphere", especially if one discusses cultural or political meaning. What is the consensus of regions? Well that depends of course, on the meaning one wants to apply to the word "region". One can use region in the sense of economical, political, and religious structures, or in the type of nature in the area (Helmfrid 1969). The common explanation of region is that it signifies a geographic area. The use of western Sweden as an example of what a region is shows us that there is also a connection between the central power and the use of the geographic and political type of region. If one tries to define it from an administrative point of view, one can place region between the central power and local community. Of course one can define regions further by viewing them as areas with strong bonds of culture or tradition that contrast clearly with surrounding areas. In addition, we have areas that are formed around a centre from an economic point of view; and these bonds can be almost as strong as the cultural bonds. But at the same time these economic bonds are not permanent, and they do not always affect all levels of membership in the community. This kind of region seems to imply that we have to work with the picture of centre and periphery before our eyes.

I see subsistence as the original basis of all human structure, and subsistence is dependent on the kind of survival strategy that can be applied to the surrounding nature (Nyqvist 2001:63-68). Of course, the technical level is important for how well humans can exploit the different natural resources. The survival strategy affects on how the society views its members, neighbours, the social strata and political structure (Nyqvist 2001:54-84). Further these types of structures affects how the survival strategy can adjust to changes in the resources or in the population. Therefore, nature can be the most basic and important factor when discussing regions. The kind of region that is based on nature can be relatively easy to detect by using maps and creating larger blocks of similar types of nature.

Hyenstrand $(1982,1984)$ worked with this kind of map construction during the mid-1980s, when he combined the natural and topographic region with the knowledge of were graves where situated in diverse sets of maps. With these combinations he could not actually construct any larger regions, but rather smaller areas that could be called small kingdoms or folklands. Although he is aware of the big problems in using the term region, he felt that it was an important instrument in the discussion concerning the constructions of archaeological rooms (Hyenstrand 1982: 55).

A different kind of structure is that which is created by political agreements, because this can include different natural zones and therefore different economical structures. This kind of structure, I believe, is the basic structure of greater kingdoms or the foundation of states. Political agreement does not have to go below the level of leaders and their followers, at least not in the beginning. When this change occurred it probably was the result of the current leaders desire to keep together the parties that newly joined together. And when possible efforts will be made to create more common symbols 
and traditions within the desirable area. The question is, can this kind of structure be counted as a region? As I pointed out earlier, I would like to see these structures as connected to the discussion of the relations among centre, semi-periphery and periphery (Nyquist 2001:46-53).

If we instead take up the question of whether we can distinguish borders between regions, we have to ask ourselves when is there a need for borders? Over time the borders have been changed, because the powers of a regional institution (such as kings or states) have demanded it. Here we have the problem of whether it is possible to detect any of these changes in the borders in our material. An action such as changing a border does not have to result in different material styles on both sides of the new border. Especially since in the beginning the people will still have the same cultural background and will have relatives living on both sides of the new border. All this is, of course, dependent on whether these changes are permanent or not. So to simplify this angle of the problem, let us work with the assumption that we actually only can detect regions that have strong bonds in culture and tradition and that make an effort to establish a contrast to surrounding regions. In this case we should have something resembling centre and periphery relations within the region (Nyqvist 2001).

If we now return to the main subject of this article, regions in Bohuslän, we can start with a descriptive picture of Bohuslän. The province of Bohuslän is usually considered a part of the Norwegian cultural and political sphere during historical periods and also in prehistoric times. This picture is largely constructed by using the historical relations as grounds for the prehistorical scene. But is this a correct picture of the province through the end of prehistoric time and also in historical times?

\section{THE HISTORICAL BACKGROUND OF THE PROVINCE OF BOHUSLÄN}

The province of Bohuslän is actually the only province in present-day Sweden that has its name from a castle. This castle was named Bohus and was the administrative centre for the southernmost part of the Norwegian medieval territory. It was built in 1308 $\mathrm{AD}$, but it became the centre for the area that corresponds to present-day Bohuslän first in the second half of the $16^{\text {th }}$ century (Lönnroth 1964).

Before the second half of the $16^{\text {th }}$ century, the province of Bohuslän was divided into three areas (fig. 1a). A northern smaller part was called Vätte, a larger part of the middle that were named Ranrike, and in the south the area was grouped under the name $\ddot{A l}$ ssyssel (Cullberg 1993). It is not clear if the two large islands in the south, Tjörn and Orust, were included in this southern area. The name of the middle part was changed in the $15^{\text {th }}$ century to Viken, which was also the name of the southern part of the kingdom of Norway in the Middle Ages. It is more common to see the area of the province Bohuslän as divided into two parts, Ranrike and $\ddot{A l}$ lvsyssel; the northern part (Vätte) is hardly ever taken into the discussion. This since no one can understand what kind of position Vätte might have had in this part of the Norwegian kingdom. This very short presentation shows that it was not until the later part of the $16^{\text {th }}$ century that there was a united province, at least on paper.

Despite this, there has always been a view that there was a common military 

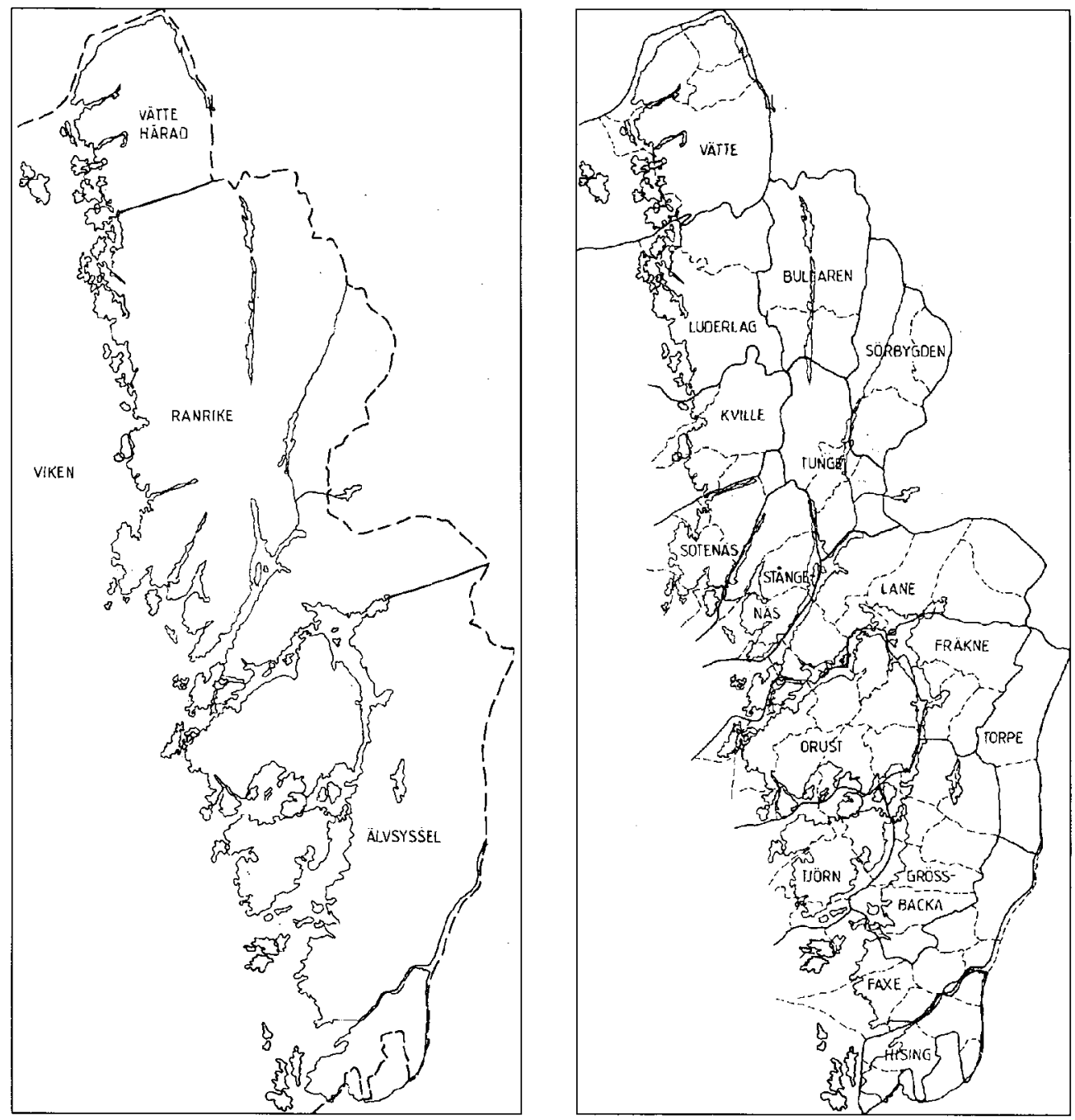

Fig. 1. a) The three areas Vätte, Ranrike and Älvsyssel. b) The sixteen skeppsredor in the province of Bohuslän. (Figures from Cullberg 1993).

organisation in this area that was called skeppsreda (fig. 1b). This was an administrative unit for the purpose of putting together one ship and crew per unit, for royal expeditions and defence (Lönnroth 1964, Cullberg 1993). We do not actually know the borders of these units (skeppsredor), but we know that there were sixteen of them. During the $17^{\text {th }}$ century these skeppsredor were renamed härad. From this point in history we can see the unit härad and its borders on maps from the $18^{\text {th }}$ and $19^{\text {th }}$ centuries. These units were not equal in size and probably not in inhabitants or in the number of men that could be enlisted. But despite this, these constructed areas were stabile and used until the reconstruction of Swedens municipal structure during the later half of $20^{\text {th }}$ century, as a base for local Swedish economical and political structure. 
According to how the area is presented in some of the interpretations of the structure of Norwegian medieval law (Smedberg 1973), one can see that the whole area of present-day Bohuslän was connected with the area around Oslo, that is Vestfold and Østfold. This large area was called Borgartings area of legislation. There does not seem to be any indication that Bohuslän was divided within this larger legislative area (fig. 2).

If we then turn to the next type of information, the churches and the influence from surrounding areas on the design of baptismal fonts, we can see that Bohuslän has had different influences in the cultural sphere concerning fonts. In Bohuslän it is possible to divide the province into a northern and a southern part. In the northern part Østfold fonts dominate, and in the south fonts from Västergötland and actually also fonts that show English influence in both form and ornamentation. In the northern area there is even a font that is typically Danish as well as fonts of a local craftsman work (Hallbäck 1961). And of course there are fonts that are unique, both in north and the south, even if the south dominates this category. All in all, one can see these fonts as indicators of different cultural spheres that have to do with who builds the churches and their connections outside Bohuslän. In the northern area there are larger parishes than in the south, which makes the landscape of power more, fragmented in the south then in the north. If, then, we take the skeppsredor into account, we see that the situation is the reverse since the southern area has the same amount of skeppsredor as the north, despite the amount of parishes.

Even on a political level Bohuslän has been sliced and tossed about between Norway, Sweden and Denmark from the year 900 to 1660 (1658), although not of course every year during this time (Lönnroth 1964; Lönn 1999). During most of this time Bohuslän was politically connected to either Norway or Denmark, or to the Union of Denmark-

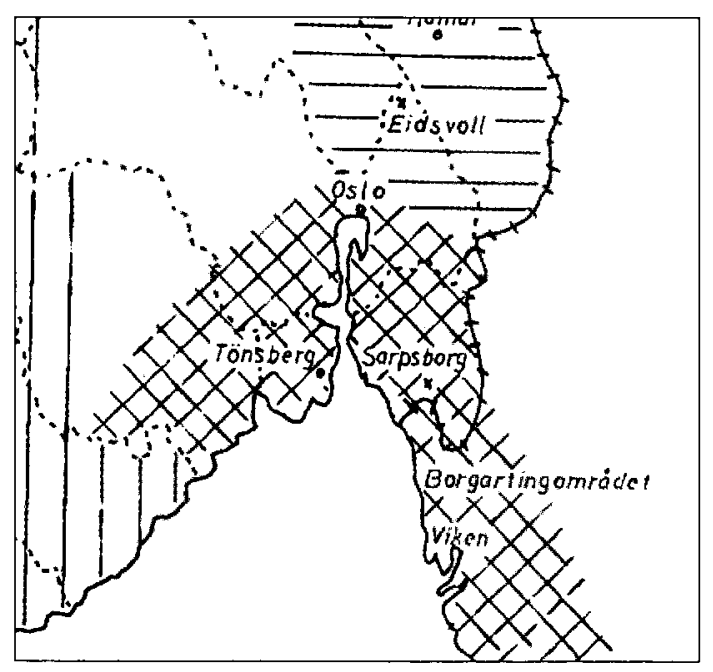

Fig. 2. The Norwegian areas of legislation during the early Middle Ages. (Part of illustration from Smedberg 1973).
Norway as a whole area or a part. In the $15^{\text {th }}$ and early $16^{\text {th }}$ centuries it was of course part of the Union of Sweden, Norway and Denmark. In this very short description of this area's political affiliation and history, I have not discussed the early $14^{\text {th }}$ century. During this period there was a weak political power in the west coastal area, and it was possible for other persons to create smaller areas by supporting different kings and gaining control of castles along the coast (Lönnroth 1964).

So what does this historical presentation show us? This area has been in the hands of all three growing national states during a period of 


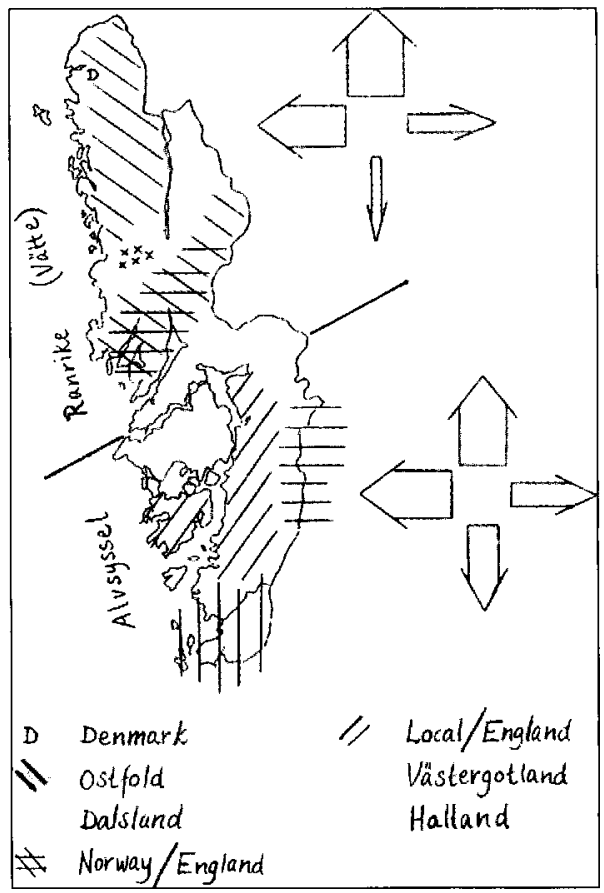

Fig. 3. The province of Bohuslän, with administrative structures and possible cultural or political spheres. The interpretation is built on the possible directions of influences on baptismal fonts as presented by Hallbäck 1961.

6-700 years (Lönn 1999). We can see that, politically there was a united area called Bohuslän in the late $16^{\text {th }}$ century. It was named after the strongest castle in this region, and although the castle was situated in the outer part of the Norwegian area, it became the administrative centre of the newly constructed province of Bohuslän. One can read between the lines here and conclude that at the time of name giving, there was no name that could be used for describing this part of Norway. There seem to be no historical connections between the parts that became the province of Bohuslän. It is even possible to detect differences in the later part of history, especially in economical settings and the dialects of the north and south (Hasslöf 1931; Lindroth 1946).

We can also see this divided area in the oldest written information we have. There were at least two, or possibly three, larger areas that were divided into sixteen smaller areas during the early Middle Ages. The question, then, is whether these larger areas could be older than the smaller units. What is the reason for these different divisions into smaller and smaller areas? Could it be a method for dismantling older constructions of some kind, perhaps federation or small kingdoms? Why didn't they who had the power choose Älvsyssel as the name for the province? Why did the name of the castle suit the purpose of the power? For, even in trying to answer this question one must turn to one of the factors that is among the most important of all categories.

\section{THE LANDSCAPE CONSISTS OF ROOMS - OR THE TOPOGRAPHIC FRAME} If one looks in a tourist brochure from Bohuslän, one can easily see that Bohuslän consists of the coastline and the cliffs and nothing more. There are seldom any descriptions that point out that the landscape consists of a great number of valleys of different sizes and different lengths. Mostly the valleys extend from west to east, and there are only a few of them that go from north to south. These kinds of landscapes always create dividers that effect how open and how easily movement in the landscape will be.

In the literature there is a very clear division of the province Bohuslän into two larger areas, with the border somewhere close to the area of the municipality of 
Uddevalla (Nyqvist 2001:20-27). Here one can see the shift between different types of rock changing from more rounded mountains in the south to steeper mountains in the north. These features naturally give the landscape more or less steep valleys, which affect the possibility to move between the valleys on land (Berglund 1989; Haglund \& Hagnell 1930). There are also larger plains, or at least flatter areas in the north than in the south of Bohuslän. There is also a difference in climate between coast and interior, as well as higher mountains in the interior (up to 224 meters above sea level) than in the coastal area. The eastern part of Bohuslän is characterised by bogs and lakes in mountain areas, which are called fjäll in Bohuslän. If we consider the soil, there are differences between the north and south, with quite an equal mixture of clay and sand in the north and more clay in the south (Ljungner 1938). Of tradition there is a picture of quite a small area that could be suitable for agricultural activities in prehistoric times (Freis 1959). But later excavations indicate that there are larger sandy areas in the south that could be used for agriculture in the valleys (Nyqvist 1992). This would probably have influenced the kind of economic structure that was possible for subsistence.

In a study of the historical cultural landscape, a picture was presented of six types (see fig. 4) of naturally and agrarian

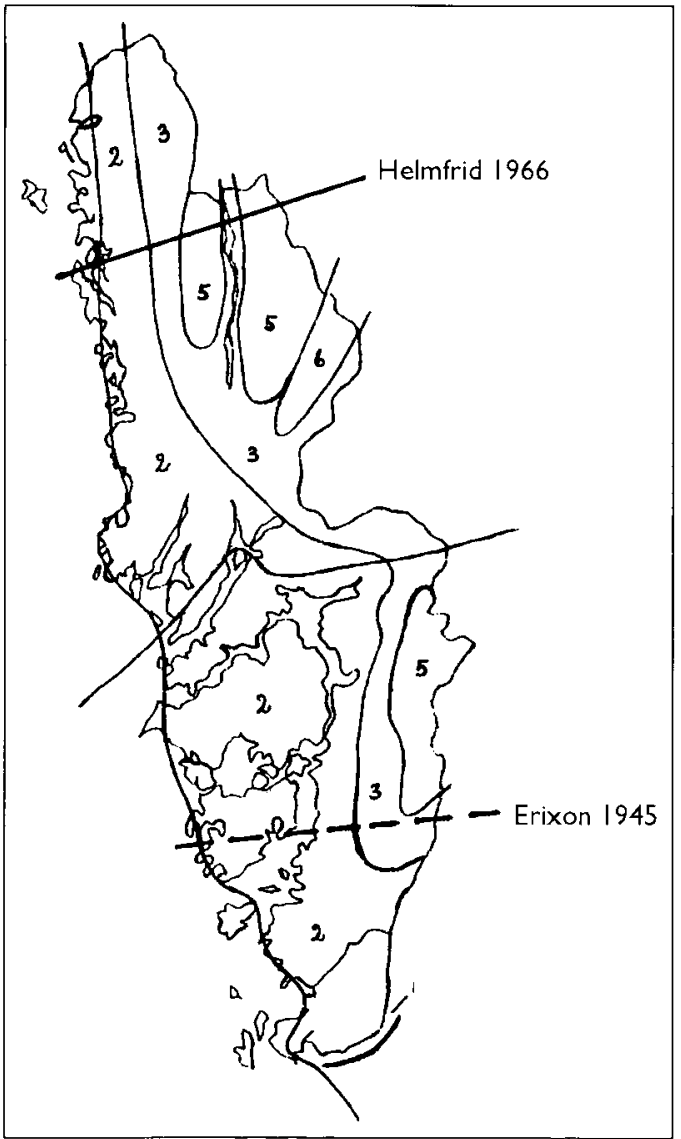
history constructed regions (Franzén et al. 2000). This picture doesn't take the natural and geographic setting into consideration. But together with the climatic difference and the picture of a landscape split by all the valleys, waterways (lakes, bogs, rivers and smaller creeks) and mountains, it confirmed how hard it is to look upon Bohuslän as one region (Nyqvist 2001:26-27). This is especially true if one wants to travel or transport goods from the north to the south, since the hills and mountains would prevent or at least make the transport very risky. If we consider cultural regions as the two most prominent researchers,

Fig. 4. The province of Bohuslän and its different types of cultural region according to Helmfrid (1969), Erixon (1945) and Franzén et al. (2000). The numbers means following; 1) coastal area. 2) middle district. 3) interior area, 4) Göta river, 5) highlands (fjäll) and finely 6) the valley of Örekils river: The province is divided into a north and a south half. 
Sigurd Erixon (1945) and Staffan Helmfrid (1969) presented them. We can see that none of them has the same border for their regions (see fig. 4). This difference comes from what kind of material they have chosen to study. Furthermore, they do not seem to have very close connections to the natural rooms indicated by the topographic settings.

\section{SIGNS AND SYMBOLS OF REGIONS IN ARTEFACTS AND MONUMENTS}

In this section I will present three levels of material. The first material and that which has been used by a large group of researchers is, of course, gold (See Lundqvist 1998; Axbo 1991; Kindgren 1992). Although this material group is quite small in both number of locations and number of items, most researchers use this category in one or another way. The second level is the material of cruciform brooches, ceramics and glass beakers (Särlvik 1982; Nyqvist 2001). The third level of material is the visible monuments or graves, and strangely enough there have been very few occasions when this group has been used to create structures in my research area (Hyenstrand 1984; Winberg 1980; Nyquist 2001).

If we concentrate on the items of gold, we can see that there is a big difference in how these items are spread in the research area. In Bohuslän there are between 40 and 50 locations with finds of gold items registered since the early $19^{\text {th }}$ century (Fredsjö 1964; Kindgren 1992). Some of these locations have no gold items preserved, and the knowledge of them consists only of some vague descriptions of both the location and the type of item found. The northern half of Bohuslän has about 60 percent of the total amount of locations for gold items (Fredsjö 1964; Kindgren 1992). Within this northern part there is also a smaller area that has more then 40 percent of the northern area's total items. If we can compare these locations with the area in the south, it becomes very clear that the south does not have the same richness as the north (Kindgren 1992). In the south there is a larger spread of the locations of gold finds over the entire area. There is no concentration as there is in the north. According to Andrén (1991:253), Bohuslän and Västergötland seem to have a closer connection to the Norwegian area. But on the other hand, Axbo (1991) shows that some finds from the geographic middle area of Bohuslän could be connected to the Danish area. Altogether this indicates that the northern area could be under the influence of the Norwegian area, and the south of Bohuslän under the influences of the Danish area.

Thus we have a very large difference in the number of locations as well as the number of items between the northern and the southern part of Bohuslän. Does this difference stem from the possibility that the north is a richer area because there was a larger population and therefore also a stabile base in the economic resources? Or does this difference exist because there were different economical and social systems? And finally, can it be dependent on when and how the material was collected?

To test this, I will use one area in the north which consists of the parishes of Kville and Tanum, and one in the south that is equivalent to the area of the present-day municipality of Stenungsund (fig. 5). These two areas are chosen because I have used them in another, recent work (Nyqvist 2001). They represent quite well the relations between the richer north and the poorer south. Between these two areas there is actually 
a very large difference in the number of locations and the number of gold finds. The northern study area has about 70 percent of the gold and silver finds and 75 percent of the glass beakers (Nyqvist 2001:157-158).

If we then look closer at the history of the finds, we will see that almost all the gold and silver artefacts were registered before the year 1900 (Nyqvist 2001:152-157). And if we compare the two areas we will find that the northern area has an almost total dominance in the period before 1900 and that this dominance changes in the period after 1900 to a level even below the southern area's number. At the same intervals we can see that the southern area has the same amount of finds registered before 1900 as after 1900. This indicates that we should be careful when working with this material. We know namely that this difference between areas comes from the fact that in the northern area there was a group of archaeologically interested people working (Nyqvist 2001:85-103). Two of the most prominent persons in this group were Oscar Montelius and Emil Ekhoff, who was worked from the late $19^{\text {th }}$ century to the early $20^{\text {th }}$ century to create the first complete summery of the monuments and artefacts for each parish. They started their work in the parishes of Kville and Tanum, probably because they had relatives in these parishes (Nyqvist 2001:85-90; Letter from George Sarauaw to Emil Ekhoff in Ekhoff archives volume 8 A.T.A.).

This kind of interest in ancient monuments and artefacts did not exist in the southern area at the same time, and it was not established for the southern area until at the earliest in the late $19^{\text {th }}$ century or early $20^{\text {th }}$ century (Nyquist 2001:91-97). This means that the agricultural expansion that took place in the period from the late $18^{\text {th }}$ century to the mid or late $19^{\text {th }}$ century was almost over in the southern area before the archaeologically interested public started to collect items from the monuments that were destroyed (Nyqvist 2001:152-157). It was almost only in folklore and barely even there that the finds and the monuments remained after they were destroyed or plundered in this southern area. This could explain the difference as well as the assumption that it is a difference in economic power that created these differences.

With regard to what some special groups of artefacts tell us of their provenance, we can for example study the pottery with asbestos or soapstone from the period from 200 to $600 \mathrm{AD}$. These artefacts show us that there is a connection with the Norwegian area and that the artefacts are quite well spread in Bohuslän, with a small dominance in the south (Nyqvist 1995). In my two study areas there is actually a reversed picture compared with the gold finds, as the southern area dominates in this ceramic group heavily. Of course the pottery that contains soapstone can be locally produced in some of the districts within Bohuslän, since soapstone occurs naturally (Hallbäck 1961). But asbestos does not exist naturally here - closest area is north of Oslo (Nyqvist 1995). The few glass beakers that are registered show a direct opposite relation, and display the same relation between my two study areas as the gold and silver. But both these two categories are a smaller material group than the gold and silver.

When we look back at the material from all of Bohuslän that has been published, we can identify the following structure in these presentations. In her study Särlviks (1982:103-118) claimed that it was possible to see, in the orientation of the graves, 


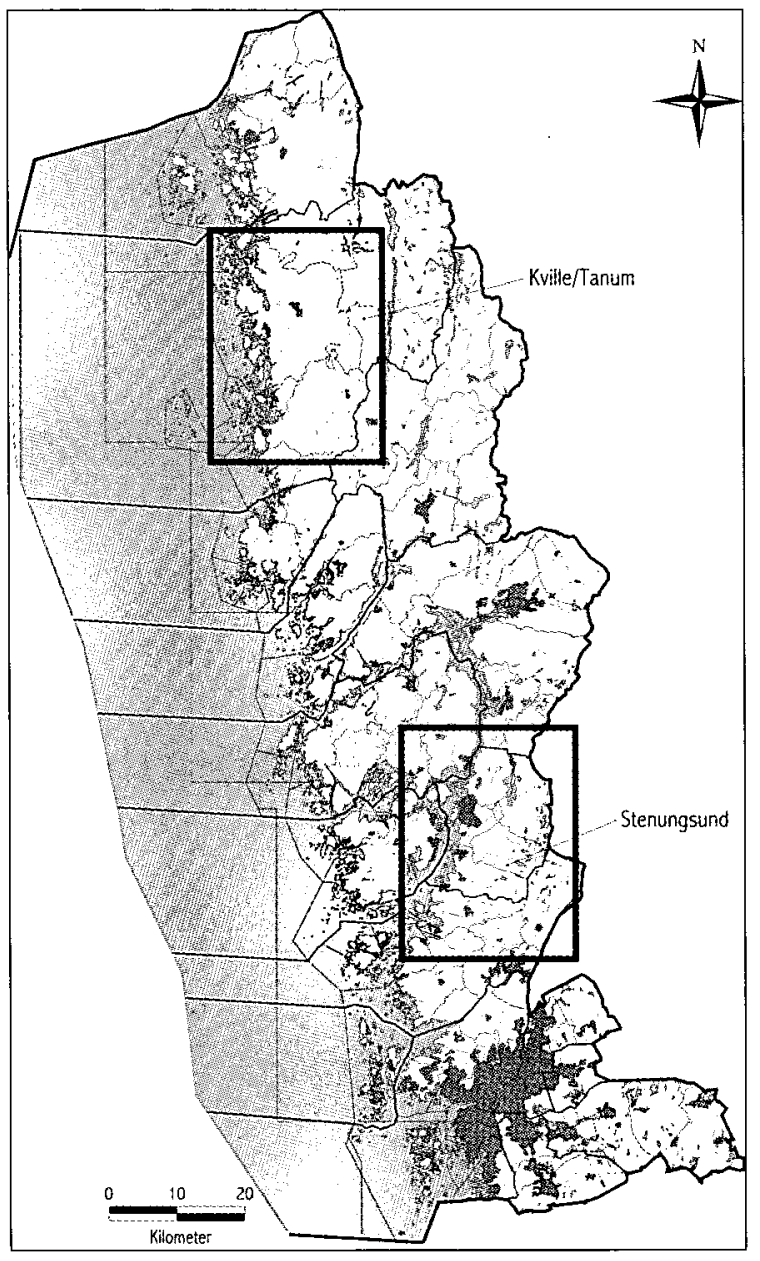

Fig. 5. The two study areas in the province of Bohuslän (from Nyqvist 2001:17).

connections with Zealand, Scania and Jutland during the period from $\mathrm{BC}$ to $600 \mathrm{AD}$. In this material, there was a stronger connection between the southern area and the Danish area during this period. And if we look at the finds of pottery, inhumations and flat bone hairpins, the Norwegian influences dominate the northern area. If we study the cruciform brooches, there will be a clear dominance in the southern area in connection with the Norwegian area. Altogether this indicates that there is a clear dominance of Norwegian influence in the material, except for the gold material and in the way the graves are oriented.

If we finally look at some facts that could point to a close mental picture, we can see that there are a few finds that indicate this. Examples of this are a ceramic vessel from the parish of Tanum in the north and another from the parish of Ytterby in the south of Bohuslän, both of which have a bit of glass in the bottom of the vessel (Sarauw \& Alin 1923). These two finds indicate at least that there could be one and the same idea behind the way they were designed (Nyquist 2001). They are from the same time span as all the other material that has been presented, that is the period between $\mathrm{BC}$ and $600 \mathrm{AD}$. We have also pottery that was created as a replica of an asbestos vessel.

There is a very small amount of late Iron Age graves and finds registered. But in these categories there, is according to Kjerstin Cullberg (1963), a clearer connection between the Norwegian area and Bohuslän. Cullberg does not divide Bohuslän into a northern and a southern area, but discusses the whole area as one.

If we instead go back to my two study areas and look at the registered monuments there, we see that the number of locations with graves varies between the north and the south. At the same time the number of graves in each cemetery from the Iron Age will not vary between these two areas if one studies them proportionally. This means that 
there is a close connection between the areas in how and why they manifest them selves with visible graves, although there are differences in the type of manifestation they choose. But this difference is greater within each study area than between them, if consideration is given to the proportional differences. According to my previous study, there are one difference in the category of mounds, the larger mounds (larger then 20 meter diameter) is mostly situated in the northern study area (Nyqvist 2001:160-175). But otherwise there seems to be more of a similar rather than different way for people to express themselves in these areas.

It seems that there may be a greater difference in the period between $\mathrm{BC}-500 \mathrm{AD}$ than during the following period. As I interpreted these artefacts and the visible monuments, there are in both categories indications of some kind of common sphere in Bohuslän. If we look briefly outside the provinces of Bohuslän, we can detect possible connections with the areas around the North Sea, including also the British Isles and the southern parts of the Baltic Sea (Hyenstrand 1984:73). This interpretation comes from the number of stones in the stone circle. The mounds are a typical grave type from around $200 \mathrm{AD}$. First as one among many types, then as the dominating type from around 5/600 AD until the later part of $900 \mathrm{AD}$ when there once again seem to be diverse grave types. We can see that there are some types of monuments that are common over larger areas and some that have different dating depending on which part of Sweden you are in. If we combine monuments, gold and silver items with the topographic, we can distinguish between eleven to sixteen districts in Bohuslän (Nyqvist 1998:381383, 2001:241-244).

\section{THE LANDSCAPE OF REGIONS, OR BEFORE AND AFTER BOHUS}

Above I presented a set of different levels of information, which can be used to define regions in Bohuslän. According to my discussion in the beginning of this paper, the meaning of the consensus of region is that there is a natural, geographic, political, economical or religious connected area. But as I stated, it is in one sense easier to discuss regions from a natural and topographic point of view. This method of constructing regions has nothing to do with the remains of the inhabitant's economic or social structure, and therefore it is possible to construct as large areas as are needed for the purpose. This kind of region consists, however of more than one natural and topographic type of landscape, so it is dependent on the kind of rough parameter one uses. I argued for the idea that there probably is, within each natural and topographic region, a common economic structure for subsistence and therefore one should find the same kind of expression of status and social structure (Nyqvist 2001:77-83).

If we in closing take all these different indications presented in this paper and put them together and compare them with one another, we find that the province of Bohuslän is a very problematic landscape to work with since it contains a great number of possible natural regions (Lönnroth 1964). And when starting to construct regions from the natural and geographic settings, we see rather quickly that it is possible there are at least two larger regions which are roughly the same as the northern and the southern half of the province of Bohuslän. As such we have two regions within the province, but 
by using the topographic structure and the cultural and agrarian history it is also possible to detect up to six types of regions. As presented in this paper, there is no historical record of a closer connection between the northern and the southern half. It is possible that the northern are is divided into two parts, and in that case how is this visible?

It seems clear that the construction of one area that is called Bohuslän, took time. It took at least 100 years after the initial construction of a province connected to the castle, probably more, before the whole area of today's province of Bohuslän was established. If we then look at the baptismal fonts and the kind of influences they indicate, it is no surprise that the part of Bohuslän that is close to the river Göta $\mathrm{A} l v$ has influences from Västergötland. The northern areas, on the other hand, have connections with the Norwegian area of Østfold and perhaps influence from the British Isles. At the same time the southern areas, particularly the areas close to Göta Älv, show another directions of influence. They seem to be more influenced by the British Isles, in a local version. This makes it clear that we have at least two different areas in the early Middle Ages (fig. 6). With regard to the division of the northern half into two, there is actually a separating indicator (the direction of influence is Danish) among the fonts which could confirm that this area could have been a separate area. But this is only one indicator among four fonts, so it is not very strong. The skeppsredor and the parishes have different signals. Concerning the parishes, there are in general many and smaller parishes in the south and fewer and larger ones in the north (there are exceptions in the north). Skeppsredor number about the same in the north and the south, so in this case the smaller areas in the form of parishes are within a larger geographic organisation (se Cullberg 1993:32-33). There is, however, no possibility to discuss what this means, other than to say that there seems to be a different history within the northern areas called Vätte and Ranrike than in the southern area of Älvsyssel.

Actually one can put forward a hypothesis that the areas of north and south reflect different social structures, and political power and by using the structure of skeppsredor the upcoming Norwegian royal power reorganised the divided political landscape into one equal structure. In this structure there would not need to be a connection with Ranrike, Vätte or Älvsyssel. They would have their connections directly with the king. The only problem is that Vätte seemed to survive this reorganisation, but the other two areas were split into fractions. This structure does not appear to have been a total success, however as still in the late $15^{\text {th }}$ century the areas were called Vätte, Ranrike and $\ddot{A l v s y s s e l}$.

If we turn to prehistoric times, we can see that there seems to be an early connection with the Norwegian area for the northern areas, while the south seems to have more connections with the entire surrounding area. The interesting thing is that the different types of prehistoric material does not point to the same directions. In some parts there are even more local connections perhaps within the area called western Sweden (see the discussion in Särlvik 1982:103-118). This is perhaps an indication of a kind of regional manifestation as a contrast to the material that is common within a larger area. Turning to the non-movable symbols such as houses or graves, find that, for all of Bohuslän, there are more connections with the Norwegian area then the Danish or the 


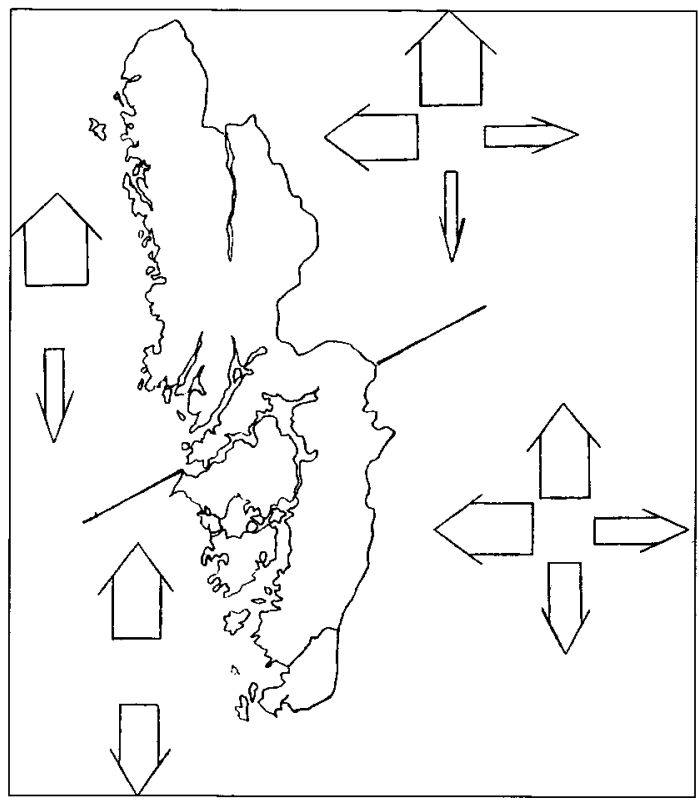

Fig. 6. Bohuslän, a province of mixed directions of influence? On the left the prehistoric and on the right the medieval directions of influences. The south direction arrow is including Danish influence.

western part of Västergötland. When one takes all the material into account, there seems to be a slight dominance for the nearest part of the Norwegian area in the entire area of Bohuslän (Nyqvist 2001:249-251).

It is, I think, possible to present the following theory concerning possible regions in Bohuslän. In the early Iron Age there are connections on the political level with a greater area, perhaps the area around the

North Sea. These political connections could change quickly, and therefore we can see mixed influences in the material. It is probably in this period that we have the first larger structures that later become Vätte, Ranrike and $\ddot{A l}$ vsyssel. During the Late Iron Age it seems difficult to detect the directions of influence, if any. This is actually the Dark Ages in this respect, while during the Middle Ages there are again remains that indicate a mixed relation. But this time we do not have so much material for comparison. The only thing we have is the political structure or simply the influences within the groups that had power.

\section{CONCLUSION - REGIONS ARE THEY REAL?}

In this paper I have discussed what a region may be and then discussed if it is possible to detect regions in Bohuslän. If one starts with the natural and geographic type of region, one has to quickly leave the natural behind because the landscape and the surrounding area does not have the same type of landscape or nature. We can construct somewhere between two and six natural regions within Bohuslän, which means that each region is a small area. Left over is the geographic region, which is the type of meaning used most often. But this doesn't have anything to do with the remains, so in this sense we can be a part of many or a few regions (just pick and chose).

If we use the religious structure as a basis for region construction, we do not have any region within or outside Bohuslän. This is because the different material I have presented indicates basically the same beliefs over a larger area. This is also why I did not even discuss religion as an aspect in this paper. Turning to the economical meaning of region, we can not actually discuss this since we don't even have a model of how the economical structures within regions were connected to each other. If we put together the economical and political spheres, it is perhaps possible to define two larger areas, 
a northern and a southern district that also can be confirmed in the natural regions. These two seemed to have economical relations and/or political connections with larger areas outside their own natural and topographical settings. But do these indications actually have any connections to lower levels in society? There does not seem to be any great difference between them in how they built graves or houses within a larger area.

The remains that we as archaeologists study are expressions and manifestations of social and cultural identities. They are constructed to be readable in a twofold sense, first within the local community and second over the large areas that are connected both economically and culturally. We would therefore not see anything but small differences when it comes to the visible structure within that which can be called a society. When we deal with the non-visible structures, such as grave gifts or the way the dead person is treated in the ritual, we should be able to detect more differences between the different topographic or natural areas. Should we view the differences in the material as an indication of remains of different structures that are active at the same time?

The biggest problem is, namely, that all the available information is from different periods within each chronological sphere and it is therefore hard to evaluate each piece of information. This is because there are problems with artefacts that can have been used as political gifts. Political connections can change many times during a century and therefore leave many different indications of directions in the connections within one and the same area. And of course the political connections only bind the political levels together; there do not have to be any connections to the surrounding natural and geographic region.

A different problem is that some of these materials have a clear relation to when and how they were discovered. From this perspective it can be difficult to use the gold artefacts since this material seems to be unequally distributed between the northern and the southern half of Bohuslän. Is this fact dependent on each area's economical background, or is it their political connections that are visible in this difference? I think that most of the difference depends on the archaeologically interested public and the presence or lack of a leading researcher in these two areas. The big difference between the north and the south regarding how and when the materials were collected can be explained by the interest in these kinds of monuments or artefacts and that this coincided with the agrarian expansion. The fact that we have a lot of material from the period of $\mathrm{BC}$ to $600 \mathrm{AD}$, can be explained by the interest in excavating the larger mounds. These mounds nearly always leave material from the period BC to $600 \mathrm{AD}$. Of course, the agrarian expansion and the fascination for large mounds can be the explanation for the lack of knowledge on the late Iron Age, since this material also was destroyed during the agricultural expansion in the $19^{\text {th }}$ century and large mounds were not built during the late Iron Age.

Here we have why it is of great importance to know the history of the different artefacts that are used in this kind of construction of political regions. Since material represents the only remains of this structure, we are in need of both a historical check 
of the individual find and some theory of why and how it was used in its own sequence of time.

Region is a construction that covers everything from landscape, people and economic structure, to nature, political structure and structures for subsistence, and this from a clearly generalising point of view without any attempt to put these different pieces of information together in an explanation of why these materials have those structures. Actually I would say that the reason for the use of region is that it is suitable for our own time, since there is a need in society for an instrument that can be used to dismantle different modern states if one wants to create a union of them.

Finely, I have to say that we can discuss and use regions in a geographic sense. But we have to bear in mind that within the region there can be many different topographic, economical, political, religious and natural areas. And these will be the reason for how and why our material remains have the shape and distribution that they do. Therefore one can not expect that it is possible to write the history of a region, and it would be a history that covers all of the geographic area (depending, of course, on how large the geographic area is). But the different materials within the region can also be the result of the history of the use of landscape and the influences that the interested group of collectors could create for the artefacts.

\section{Enlish revised by Laura Wrang.}

\section{REFERENCES}

Andrén, A. 1991. Guld och makt - en tolkning av de skandinaviska guldbrakteaternas funktion. In: Fabech, C \& Ringtved, J (Eds). Samfundsorganisation og Regional variation. Norden i romersk jernalder og folkvandringstid: Beretning fra 1. nordiske jernalderssymposium på Sandbjerg Slot 11-15 april 1989. Højbjerg. Pp. 245-256

Axbo, M. 1991. Guld og guder i folkevandringstiden. In: Fabech, C \& Ringtved, J (Eds). Samfundsorganisation og Regional variation. Norden i romersk jernalder og folkvandringstid:. Beretning fra 1. nordiske jernalderssymposium på Sandbjerg Slot 11-15 april 1989. Højbjerg. Pp.187-202.

Berglund, J. 1989. BOHUSLÄNS GEOLOGI. Bohusläns museum. Uddevalla.

Cullberg, C. 1993. Bohuslän-ett gränslands historia. Uddevalla

Cullberg, Kj. 1963. Gravformer i Bohuslän och Östfolds vikingatid. Essay, not printed, Göteborgs Universitet. Arkeologiska Institutionen.

Erixon, S. 1945. Svenska kulturgränser och kulturprovinser. Stockholm

Franzén, B-M. \& Lindholm, K. 2000. Agrarhistorisk landskapsanalys över f.d. Göteborgs och Bohus län. Landskapsprojektet 2000:8. RAÄ and BM. Stockholm. With contributions of Uddén, J and Carlsson, H. Fredsjö, Å. 1964. Bohuslänska fornsaker av guld. En översikt. In: Bohusläns Hembygdsförbunds Arsskrift. Uddevalla. Pp. 7-39.

Fries, M. 1959. "Vegetationslandskapets historia i Bohuslän" In: Skottberg, C \& Curry-Lindahl, K. (Eds). Natur i Bohuslän. Uppsala. Pp. 407-419.

Haglund, A. och Hagnell, A. 1930. Bohuslän. En bok för skola och hem. C. W. K. Gleerups Förlag. Lund. Second edition. 
Hallbäck, S. A. 1961. Medeltida dopfuntar i Bohuslän. Vänersborg

Hasslöf, O. 1931. Kulturgränser i Bohuslän In: Göteborg och Bohusläns Fornminnesförenings tidskrift. 1930. Pp. 42-60.

Helmfrid, S. 1966. Det äldre agrarlandskapet In: Sveriges land och folk. Stockholm. Pp. 150-170.

- 1969. Bruk och missbruk av regionbegreppet. In: Ymer. Pp. 17-30.

Hyenstrand, §. 1982. Forntida samhällsformer och arkeologiska forskningsprogram. Stockholm.

- 1984. Fasta fornlämningar och Arkeologiska regioner. RAÄ 1984:7. Stockholm.

Kindgren, H. 1992. Guldet från Kville. In. Bohuslän. Arsbok 1992. Uddevalla.

Lindroth, H. 1918. Bohusläns härads- och sockennamn. Göteborg

- 1946. Bohuslänska ortnamn och bohuslänsk bebyggelsehistoria. In: Göteborg och Bohusläns Fornminnesförenings tidskrift. 1945. Pp. 1-116.

Ljungner, E. 1938. Terräng och jordbruksbebyggelse i Bohuslän. In: Vikarvet 1938/39. Lysekil. Pp. 1150.

Lundqvist, L. 1998. Centralplatser och centralområden i Västsverige. In: L, Larsson \& B, Hårdh.(Eds). Centrala platser - Centrala frägor Lund. Pp. 189-203.

Lönn, M. Karlsson. 1999. Fragment av samtal Tvärvetenskap med arkeologi och ortnamnsforskning i bohuslänska exempel. Printed by Riksantikvarieämbetet, Department for archaeological excavation and Umeå Universitet nr 12. Göteborg.

Lönnroth, E. 1963. Bohusläns historia. In: E, Lönnroth (Eds). Bohusläns historia. Almqvist \& Wiksell. Uppsala. Pp. 79-364.

Nyqvist, R. 1991. Ett asbestkärl i Bohuslän. In: FYND 1/91. Pp. 61-66.

- 1992. En välanvänd åker - vad som göms i jord kommer fram vid.... In: FYND 1/92. Pp. 32-37.

- 1995. Asbest- och täljstensmagrad keramik. In: Johansson,N. Tre boplatser i Spekerödsdalen. E6 198689 del 3. Pp. 33-38.

- 1998. Central places - few postholes and gold or lots of postholes and little gold? About the magic of gold and the damnation of postholes. In: A-C Andersson, $\AA$, Gillberg, O, W, Jensen, H, Karlsson; M, V, Rolöf(Eds). THE KALEIDOSCOPIC PAST. Proceeding of the $5^{\text {th }}$ Nordic TAG Conference Göteborg, 2-5 April 1997. Pp. 369-384.

-2001. Landskapet som ram - hus och grav som manifest. A seminar version for $\mathrm{PhD}$ degree, copied not printed. Department of Archaeology, Gothenburg University.

Sarauw, G \& Alin, J. 1923. Göta älvdalens fornminnen. Göteborg.

Smedberg, G. 1973. Nordens första kyrkor: En kyrkorättslig studie. Lund.

Särlvik, I. 1982. Paths towards s stratified society. A study of Economic, Cultural and Social Formations in South-West Sweden during the Roman Iron Age and the Migration Period. Stockholm.

Winberg, B. 1980. Bohuslänska järnåldersgravfält - ett försök till strukturering. In: Hyenstrand, Å (Ed). INVENTORI IN HONOREM: En vänbok till Folke Hallberg. Pp. 220-228 